\title{
Micro-Tuber Production in Diploid and Tetraploid Potato after Gamma Irradiation of in Vitro Cuttings for Mutation Induction
}

\author{
Souleymane Bado ${ }^{*}$, Margit Laimer², Ndiogou Gueye ${ }^{3}$, Ndeye Fatou Deme³, Enoch Sapey4, \\ Abdelbagi Mukhtar Ali Ghanim', Vivian Carol Blok ${ }^{5}$, Brian Peter Forster ${ }^{1,6}$ \\ ${ }^{1}$ Plant Breeding and Genetics Laboratory (PBGL), Joint FAO/IAEA Division of Nuclear Techniques in Food and Agriculture, \\ FAO/IAEA Laboratories, Seibersdorf, Austria \\ ${ }^{2}$ Plant Biotechnology Unit, Department of Biotechnology, University of Natural Resources and Life Sciences, \\ Vienna, Austria \\ ${ }^{3}$ Biotechnology Laboratory of Mushrooms, Department of Plant Biology, Faculty of Sciences \& Techniques, \\ University of Cheikh Anta Diop, Dakar Fann, Sénégal \\ ${ }^{4}$ Council for Scientific and Industrial Research (CSIR)-Oil Palm Research Institute (OPRI), Kade, Ghana \\ ${ }^{5}$ The James Hutton Institute, Errol Rd, Invergowrie, Dundee, UK \\ ${ }^{6}$ BioHybrids International Ltd., Reading, UK \\ Email: *bado_souleymane@hotmail.com
}

How to cite this paper: Bado, S., Laimer, M., Gueye, N., Deme, N.F., Sapey, E., Ghanim, A.M.A., Blok, V.C. and Forster, B.P. (2016) Micro-Tuber Production in Diploid and Tetraploid Potato after Gamma Irradiation of in Vitro Cuttings for Mutation Induction. American Journal of Plant Sciences, 7, 1871-1887.

http://dx.doi.org/10.4236/ajps.2016.714173

Received: July 28, 2016

Accepted: September 26, 2016

Published: September 29, 2016

Copyright $\odot 2016$ by authors and Scientific Research Publishing Inc. This work is licensed under the Creative Commons Attribution International License (CC BY 4.0).

http://creativecommons.org/licenses/by/4.0/ (c) (i) Open Access

\begin{abstract}
Micro-tubers are important propagules in potato breeding and potato production, and they are also dormant and easily transported and therefore good targets for mutation induction in potato mutation breeding. A prerequisite for mutation breeding is to determine optimal mutation treatments. Therefore, radio-sensitivity tests of a tetraploid and a diploid potato to gamma irradiation were undertaken. Effects of different gamma sources on radio-activity were also studied. In vitro potato cuttings were gamma irradiated using a wide dose range $(0,3,6,9,12,15$ and $20 \mathrm{~Gy})$. The irradiated cuttings were then cultured to induce micro-tubers directly in vitro. Microtuber morphotypes were assessed after irradiation of cuttings using three gamma sources with emission activities of 1.8, 7.07 and $139 \mathrm{~Gy} / \mathrm{min}$. The diploid species (Solanum verrucosum) was more radio-sensitive than the tetraploid cultivar Desirée (Solanum tuberosum). Gamma dose rates had significant influences on subsequent micro-tuber production at various mutant generations. Effects included reductions in the number, size and weight of micro-tubers produced. Gamma dose was more lethal for the diploid potato genotype and micro-tubers produced were small compared to those produced by the tetraploid genotype after irradiation. Different treatments are recommended for diploid and tetraploid potato irradiation in producing large mutant micro-tuber populations. The mutant micro-tuber populations may
\end{abstract}


then be screened for interesting mutations/trait for both genetics and plant breeding purposes.

\section{Keywords}

Potato, in Vitro Cuttings, Micro-Tubers, Mutation Induction, Gamma Irradiation, Mutant Populations, Recommended Dose Rates

\section{Introduction}

Potato (Solanum spp.) is the most important non-cereal crop worldwide and ranks the fourth after maize, rice and wheat [1]. Potato production faces major challenges including low multiplication rates in the field under conventional (biological) seed production and yield losses due to susceptibilities to diseases and pests such as late blight disease, potato cyst nematode and Colorado beetle [2]-[6]. In production fields, many traditional cultivars suffer from poor yield with reduced tuber size and carry undesirable traits, such as sunken eyes, susceptible to blight disease and cyst nematodes, which result in reduced yield and quality. Improvements of potato by breeding are hampered by local preferences for old traditional cultivars in many parts of the world.

Potato is predominantly vegetatively propagated by tubers and mini-tubers with true seed propagation being deployed mainly for breeding purposes [7]. Additionally, axillary buds, cuttings, synthetic seeds and micro-tubers can be used as propagules. The Solanum genus is composed of over 160 species (wild and cultivated) which provide a large gene pool for crop improvement [8]. Despite the large germplasm resources, success in breeding new cultivars has been slow and genetic variability among elite lines is narrow. China has the biggest potato production in the world; however, Chinese potato cultivars show a low genetic diversity due to shared pedigrees [5] [9]. The loss of genetic diversity in cultivars may eventually lead to an increased vulnerability to new abiotic and biotic stressors, especially those directly and indirectly arising from changing climatic conditions. The narrowing of the genetic base of commercial cultivars is a primary cause of stagnation in yield improvement [10].

Micro-tubers as potato propagules can be produced in large numbers all year-round; there is no need for immediate planting, since micro-tubers are dormant and can be easily stored and transported [11] [12]. Disease free micro-tubers produced in tissue culture laboratories have been shown to enhance yield [13]. They not only represent convenient planting materials, but can be utilized in potato improvement schemes, including mutation breeding methods.

In vitro culture of vegetatively propagated crops in combination with irradiation for induced mutation has proven to be a valuable method to broaden the genetic variability of crop plants and promotes the production of new cultivars. Although potato mutation breeding started in 1931 with the pioneering work of Asseyeva [14], very few mutant potato cultivars exist: to date only 6 potato mutants (from irradiation and somaclonal variation) have been registered in the FAO/IAEA Mutants Variety Database as opposed 
to 815 for rice (http://mvd.iaea.org). This low number reflects the protracted breeding methods used which generally do not employ modern biotechnologies to accelerate the breeding process. However, they are some considerable successes in traits such as modified starch biosynthesis [15] [16], increased yield [7] [17], modified histological and texture properties [18], longer shelf-life [19] and increased tolerance to abiotic and biotic stresses [20]-[22].

In vitro biotechnologies offer new potential in accelerating mutation breeding in potato. Micro-cuttings may be used as targets for mutation induction, and subsequent micro- propagation may be used to dissolve chimeras, and large mutant micro-tuber populations may be produced at various vegetative generations that may then be used in large scale screening for the desired traits. We describe the effects of gamma irradiation treatments on in vitro micro-cuttings and the subsequent development of mutant micro-tuber populations which may then be tested for new traits such as cyst nematode resistance; mutant populations in the form of micro-tubers provide convenient starting materials for researchers and growers. Gamma irradiation was selected as it is the most widely used mutagenic treatment in crop improvement [23]. Since both diploid and tetraploid potato species are grown as crops, studies were conducted on a diploid wild species of Solanum verrucosum and a tetraploid cultivar of Solanum tuberosum.

\section{Materials and Methods}

\subsection{Plant Material and Tissue Culture Conditions}

Two potato genotypes were compared: Solanum verrucosum genotype 1/3/3/15 (Ver54, diploid, $2 \mathrm{n}_{\Perp} 2 \mathrm{x}_{\Perp} 24$ ) and Solanum tuberosum (cv. Desirée, tetraploid, $2 \mathrm{n}_{=} 4 \mathrm{x}_{\sharp} 48$ ), both were supplied to the FAO/IAEA Plant Breeding and Genetics Laboratory, Seibersdorf, Austria as in vitro cuttings from The James Hutton Institute, Invergowrie, UK. The cuttings were micro-propagated as single node sub-cultures on MS basal medium [24] supplemented with $2 \%$ sucrose and $0.18 \%$ gelrite as a gelling agent. Developing shoots were sub-cultured every 2 - 3 weeks and maintained in controlled environment conditions with 16 hours fluorescent light $(65 \mu \mathrm{mol} / \mathrm{m} 2 / \mathrm{s}$; using Cool White fluorescent tubes, Philips TLP $36 / 86$, Philips, Amsterdam, the Netherlands) at $22^{\circ} \mathrm{C} \pm 2{ }^{\circ} \mathrm{C}$. Rounds of sub-culturing continued until sufficient plant material was available for mutation induction (about 1,000 plantlets with 3-5 nodes each).

In order to investigate ploidy and genotype responses to micro-tuber production following gamma irradiation, single node cuttings with a subtending leaf were transplanted to a micro-tuber induction medium containing MS basal nutrients supplemented with $4 \mathrm{mg} / \mathrm{l}$ Kinetin, $8 \%$ sucrose and $0.18 \%$ gelrite (optimal tuberization medium). The $\mathrm{pH}$ was adjusted to 5.8 . Cultures were incubated in the dark at $22^{\circ} \mathrm{C} \pm 2{ }^{\circ} \mathrm{C}$ and micro-tubers were harvested or subjected to radiation sensitivity evaluations after 6 weeks of incubation.

\subsection{Irradiation Methods}

Gamma irradiation treatments were carried out on nodal cuttings with a single leaf. A 
radio-active cobalt-60 (gamma source) with a low and high emission rates were used to determine the optimal dosage for mutation induction and subsequent tuberization. The $\mathrm{LD}_{30}$ and $\mathrm{LD}_{50}$ (30\% and $50 \%$ lethality dose) levels were determined after exposing cuttings to a range of irradiation doses and then determining micro-tuber production using methods described by Mba et al. [25]. Additionally, the $\mathrm{GR}_{30}$ and $\mathrm{GR}_{50}(30 \%$ and $50 \%$ growth reduction dose) were estimated based on the micro-tuber size and weight. Different gamma dose rates from three different Gamma-cells of varying radio-activity (1.8, 7.07 and $139 \mathrm{~Gy} / \mathrm{min}$ ) were used to assess the effects of gamma irradiation on the micro-tubers $\left(\mathrm{M}_{1} \mathrm{~V}_{2}\right)$ produced from the two genotypes (Table 1).

To determine the optimal dose for mutation, single node stem cuttings with one leaf $\left(\mathrm{M}_{0}\right)$ were irradiated and then cultured to induce micro-tubers directly in vitro $\left(\mathrm{M}_{1} \mathrm{~V}_{1}\right)$ cuttings. Two replications of about 20 culture tubes, each containing one axial meristem was used per dose, ranging from $0,3,6,9,12,15$ and 20 Gy using which 1.8 Gy/min gamma cell. The tuberization rate (after 6 weeks incubation in the dark) was scored and used to determine the optimal dose for mutation induction. The established optimal dose for each genotype was then deployed for bulk irradiation. Data on the tuberization rate, micro-tuber position, fresh weight and size were recorded at harvest, at least six weeks after culturing the nodal cuttings.

Micro-tuber morphology was recorded by size in 5 classes: $2-4 \mathrm{~mm},<4-6,<6-8$, $<8-10$ and $<10$ and by weight in 7 classes of $50 \mathrm{mg}$ per class range from 0 to 300 , and above 300mg. The tuber position on the stolon was recorded as basal (B) when induced immediately in the meristem with no stolon development, middle (M) and top (T) when the meristem developed as a stolon and then produced the micro-tuber in the middle or at the end of the stolon. Each position or size and weight class was expressed as a percentage of the total micro-tubers produced per gamma irradiation treatment.

Analysis of variance and least significant differences of means (5\% level) were calculated using GenStat Release 9.2 for in vitro cuttings and position, size and weight of micro-tubers produced by JMP statistics packages 12 .

\section{Results}

\subsection{Effects of Gamma Irradiation on Micro-Tuber Induction}

Gamma irradiation retarded tuberization of both genotypes. While in the control, in-

Table 1. Exposure time needed for three gamma cell with different dose rate to administer the optimal dose of 10 and 12 Gy respectively for diploid and tetraploid genotype for large micro-tubers population development.

\begin{tabular}{ccc}
\hline & \multicolumn{2}{c}{ Exposure time } \\
\cline { 2 - 3 } Gamma cell/emission & $10 \mathrm{~Gy}$ & $12 \mathrm{~Gy}$ \\
\hline $1.8 \mathrm{~Gy} / \mathrm{min}$ & $5 \mathrm{~min} 33 \mathrm{~s}$ & $6 \mathrm{~min} 40 \mathrm{~s}$ \\
$7.07 \mathrm{~Gy} / \mathrm{min}$ & $1 \min 25 \mathrm{~s}$ & $1 \mathrm{~min} 41 \mathrm{~s}$ \\
$139 \mathrm{~Gy} / \mathrm{min}$ & $0 \min 4 \mathrm{~s}$ & $0 \mathrm{~min} 5 \mathrm{~s}$ \\
\hline
\end{tabular}


duction of micro-tubers started in the first week of incubation in the tetraploid $S$. tuberosum cv. Desirée, the diploid $S$. verrucosum genotype Ver54 did not initiate micro-tubers until week 2. Irradiation induced delays in the appearance of the micro-tubers was most apparent after 3 weeks for the high dose treatments of in vitro cuttings. The number of micro-tubers produced decreased with increasing dose of gamma irradiation (Figure 1 and Figure 2). Analysis of variance for the effects of gamma irra-

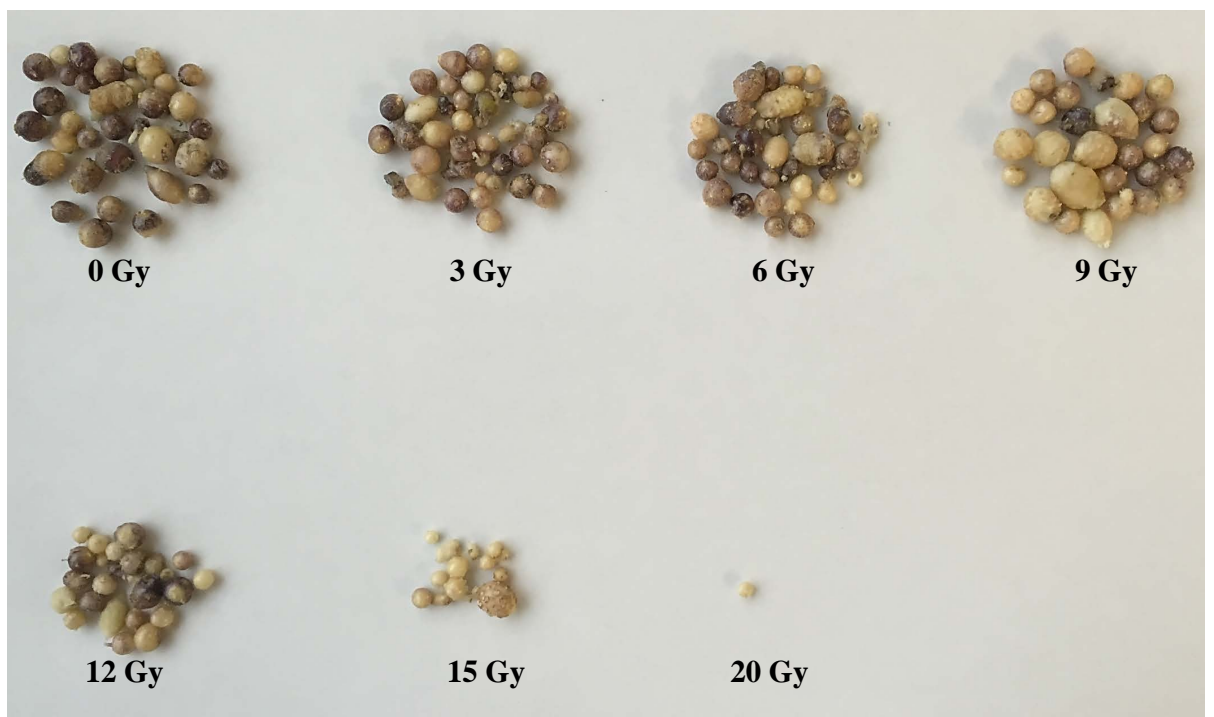

Figure 1. Effect of gamma irradiation dose on micro-tuber production of $S$. verrucosum genotype Ver54 $(2 \times)$. The number of micro-tubers produced diminished with increasing gamma dose, treatments above 12 Gy reduced number, size and weight of micro-tubers.

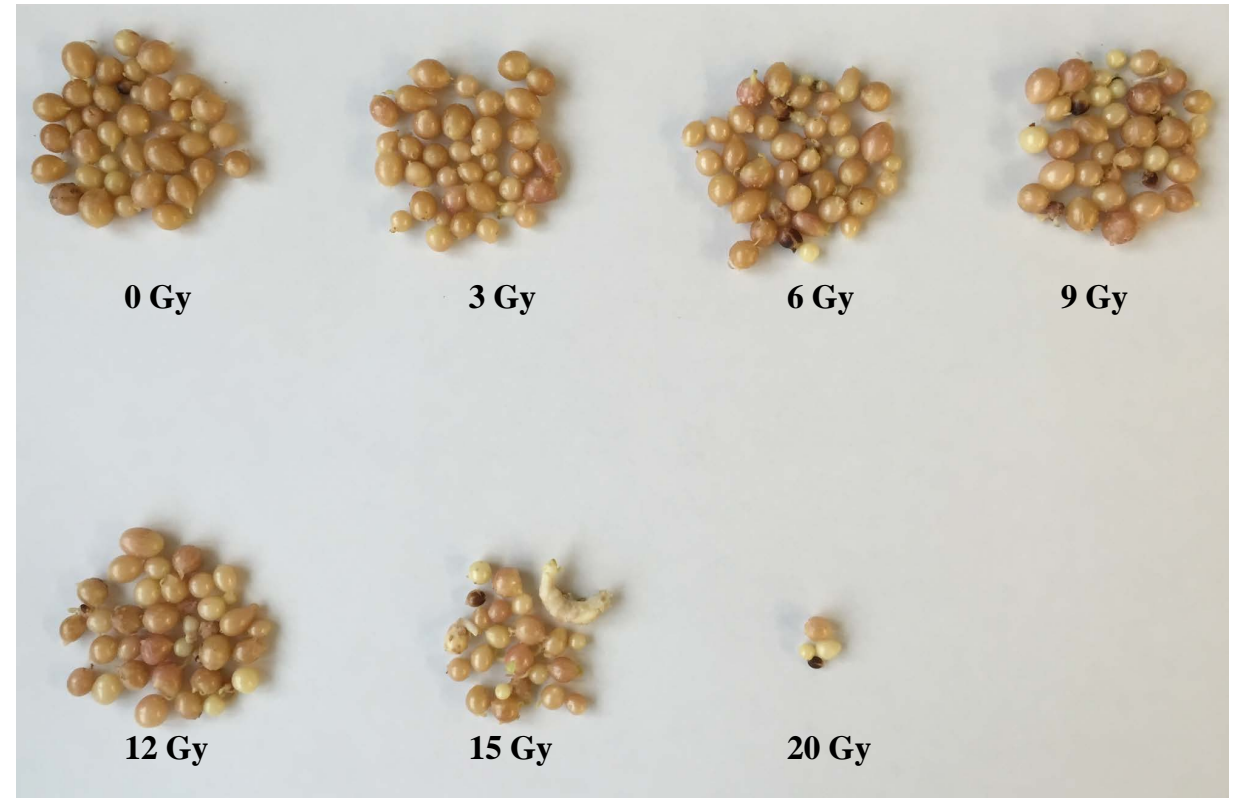

Figure 2. Effect of gamma irradiation treatments on micro-tuber production of $S$. tuberosum cv. Desirée $(4 \times)$. The tuberization rate diminished with increasing gamma dose, with doses above 12 Gy reducing number, size and weight of micro-tubers. 
diation doses and two potato genotypes revealed significant difference between genotypes in tuberization ability and micro-tuber size whereas no significant difference was found in micro-tuber weight (Table 2). This severely affected the tuberization of the diploid genotype (Table 3). Interestingly, doses below or equal to 6 Gy showed a stimulatory effect on tuberization in both genotypes. High doses above 12 Gy resulted in a delay in tuberization and inhibitory effects on the induction rate of the micro-tubers (Figure 3 and Figure 4). Micro-tuber position, size and weight were recorded in each treatment in order to determine the optimal dose for mutation induction. The effects of gamma irradiation doses on micro-tuber size and weight were discriminative above 12

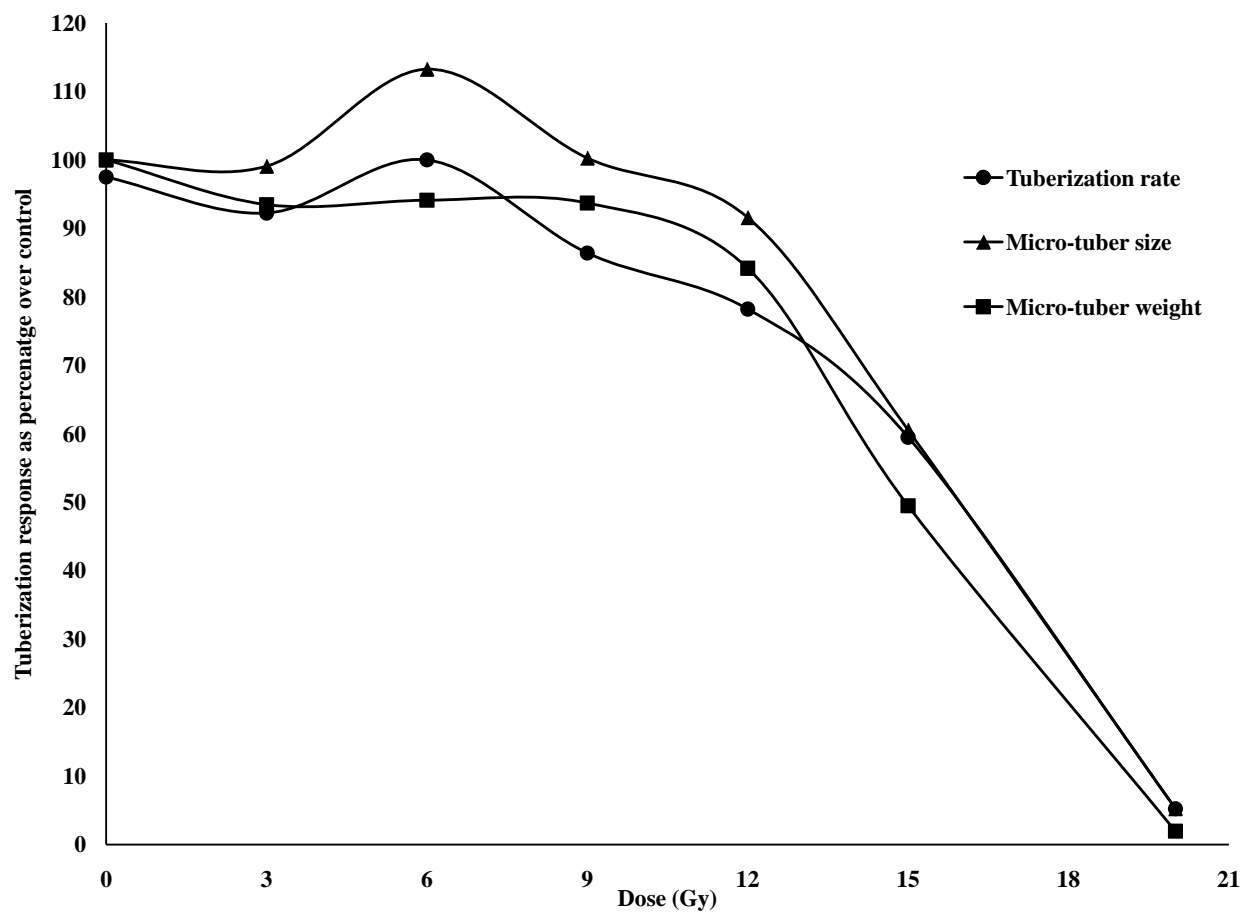

Figure 3. Radio-sensitivity graphs showing the effects of gamma irradiation on diploid (S. verrucosum,Ver54) with respect to the number of micro-tubers produced, micro-tuber size and weight after six weeks incubation.

Table 2. Analysis of variance on tuberization rate, micro-tuber size and weight between two potato genotypes: $S$. verrucosum $(2 \times)$ and $S$. tubersosum cv. Desiree $(4 \times)$.

\begin{tabular}{ccccccccc}
\hline \multirow{2}{*}{ Source of variation } & DF & \multicolumn{2}{c}{ Tuberization } & Micro-tuber size (mm) & \multicolumn{2}{c}{ Micro-tuber (mg) } \\
\cline { 3 - 8 } & & $\begin{array}{c}\text { Means } \\
\text { Square }\end{array}$ & F-Value & $\begin{array}{c}\text { Means } \\
\text { Square }\end{array}$ & F-Value & $\begin{array}{c}\text { Means } \\
\text { Square }\end{array}$ & F-Value \\
\hline Dose (Gy) & 6 & 4513.49 & $236.10^{*}$ & 16.63890 & $194.50^{*}$ & 7.6554 & $69.61^{*}$ \\
Genotype & 1 & 1298.11 & $67.90^{*}$ & 5.21833 & $61.00^{*}$ & 1.1216 & $10.20 \mathrm{~ns}$ \\
Dose (Gy)*Genotype & 6 & 139.84 & $7.32^{*}$ & 0.50672 & $5.92 \mathrm{~ns}$ & 0.4369 & $3.97 \mathrm{~ns}$ \\
Residual & 13 & 19.12 & & 0.08555 & & 0.1100 & \\
Total & 27 & & & & & & &
\end{tabular}

$\mathrm{DF}=$ Degree of Freedom; ${ }^{\star}$ denote significant differences at $5 \%$ probability level; ns = not significant. 


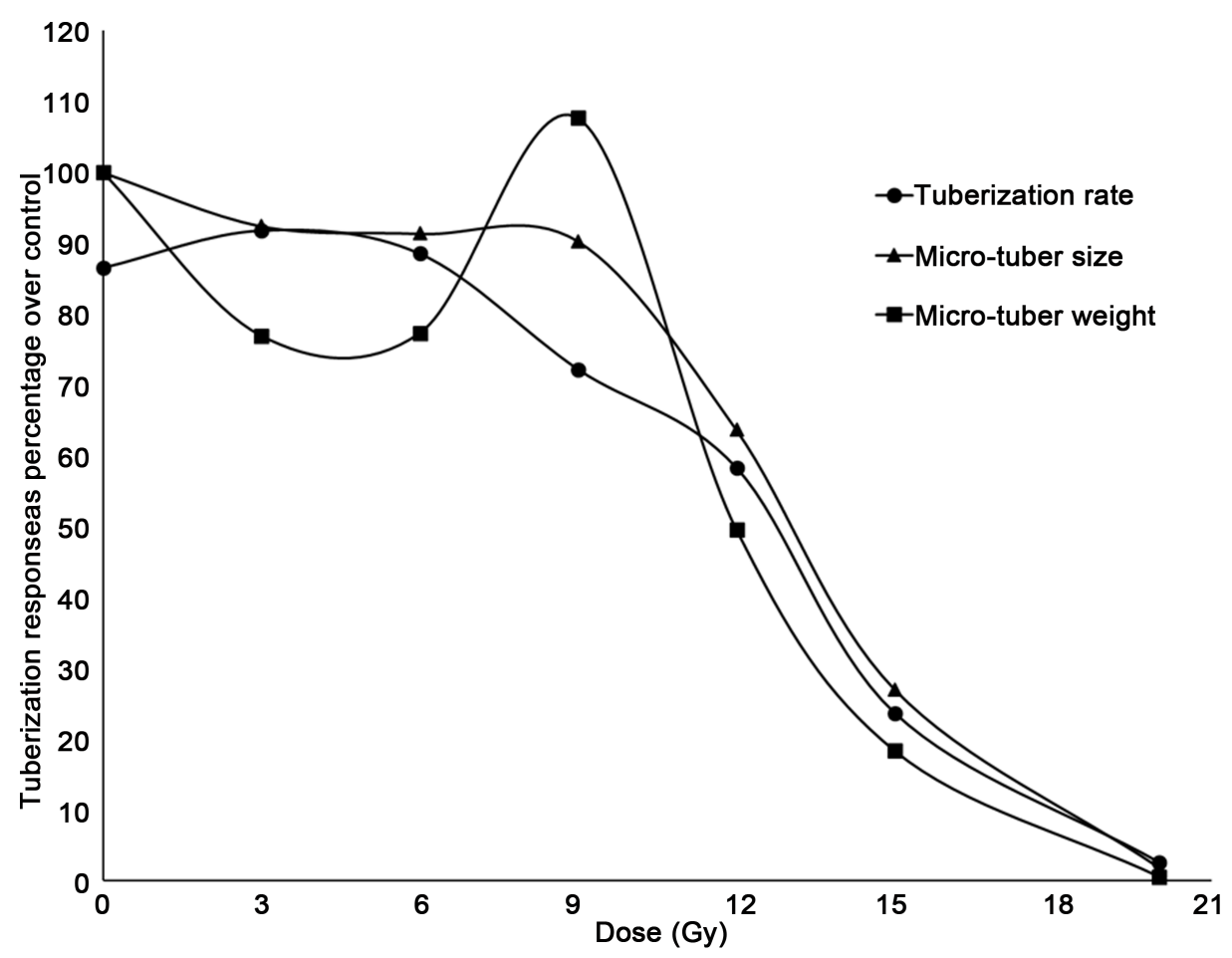

Figure 4. Radio-sensitivity graphs showing the effects of gamma irradiation on tetraploid ( $S$. tuberosum, cv. Desirée) with respect to micro-tuber production (numbers of micro-tubers), micro-tuber size and weight after six weeks incubation.

Table 3. Mean and standard deviation of in vitro tuberization ability rate, micro-tuber size and weight with their respective estimated mutation induction dose $\left(\mathrm{LD}_{30}-\mathrm{LD}_{50} / \mathrm{GR}_{30}-\mathrm{GR}_{50}\right)$ for two potato genotypes: $S$. verrucosum $(2 \times)$ and $S$. tubersosum cv. Desiree $(4 \times)$.

\begin{tabular}{|c|c|c|c|c|c|c|}
\hline \multirow{2}{*}{ Dose } & \multicolumn{2}{|c|}{ Tuberization (\%) } & \multicolumn{2}{|c|}{ Micro-tuber size (mm) } & \multicolumn{2}{|c|}{ Micro-tuber (mg) } \\
\hline & Desirée & Ver54 & Desirée & Ver54 & Desirée & Ver54 \\
\hline 0 & $97.50 \pm 3.54 \mathrm{ab}$ & $86.55 \pm 3.31 \mathrm{a}$ & $5.53 \pm 0.25 b$ & $5.45 \pm 0.40 \mathrm{a}$ & $116.1 \pm 3.2 \mathrm{a}$ & $118.8 \pm 8.0 \mathrm{a}$ \\
\hline 3 & $92.24 \pm 3.91 \mathrm{ab}$ & $91.81 \pm 4.14 \mathrm{a}$ & $5.47 \pm 0.30 \mathrm{~b}$ & $5.04 \pm 0.13 a$ & $108.5 \pm 9.7 \mathrm{ab}$ & $91.4 \pm 0.2 b$ \\
\hline 6 & $100.00 \pm 0.0 \mathrm{a}$ & $88.56 \pm 0.46 a$ & $6.26 \pm 0.01 \mathrm{a}$ & $4.98 \pm 0.19 b$ & $109.2 \pm 11.1 \mathrm{ab}$ & $91.8 \pm 10.5 b$ \\
\hline 9 & $86.40 \pm 4.34 \mathrm{~b}$ & $72.22 \pm 0.46 \mathrm{~b}$ & $5.54 \pm 0.06 \mathrm{~b}$ & $4.92 \pm 0.19 b$ & $108.8 \pm 5.2 \mathrm{ab}$ & $127.9 \pm 8.6 \mathrm{a}$ \\
\hline 12 & $78.21 \pm 9.60 c$ & $58.33 \pm 3.93 c$ & $5.06 \pm 0.62 c$ & $3.47 \pm 0.20 c$ & $97.7 \pm 14.7 \mathrm{~b}$ & $59.0 \pm 23.5 c$ \\
\hline 15 & $59.50 \pm 2.27 \mathrm{~d}$ & $23.68 \pm 3.72 \mathrm{~d}$ & $3.35 \pm 0.33 \mathrm{~d}$ & $1.47 \pm 0.0 \mathrm{~d}$ & $57.4 \pm 12.9 \mathrm{c}$ & $21.8 \pm 6.2 \mathrm{~d}$ \\
\hline 20 & $5.26 \pm 7.44 \mathrm{e}$ & $2.63 \pm 3.72 \mathrm{e}$ & $0.29 \pm 0.41 \mathrm{e}$ & $0.11 \pm 0.15 \mathrm{e}$ & $2.3 \pm 3.2 \mathrm{~d}$ & $0.7 \pm 1.0 \mathrm{e}$ \\
\hline $\mathrm{CV} \%$ & \multicolumn{2}{|c|}{6.5} & \multicolumn{2}{|c|}{7.2} & \multicolumn{2}{|c|}{13.2} \\
\hline LSD (5\% level) & \multicolumn{2}{|c|}{6.68} & \multicolumn{2}{|c|}{0.45} & \multicolumn{2}{|c|}{16.02} \\
\hline $\mathrm{LD}_{30} / \mathrm{GR}_{30}(\mathrm{~Gy})$ & 13.6 & 9.4 & 14.2 & 11.5 & 13.5 & 11.0 \\
\hline $\mathrm{LD}_{50} / \mathrm{GR}_{50}(\mathrm{~Gy})$ & $16.0 \mathrm{~A}$ & $12.8 \mathrm{~B}$ & $16.0 \mathrm{~A}$ & $13.0 \mathrm{~B}$ & $15.0 \mathrm{~A}$ & $12.0 \mathrm{~B}$ \\
\hline
\end{tabular}

${ }^{*}$ Means followed by the same letter do not differ significantly at $\mathrm{p}=0.05$ according to the Least Significance difference. 
Gy (Table 3) while the same small, medium and big micro-tubers were induced in each dose (Figure 1 and Figure 2). The position of micro-tubers on the stolon was mainly at the base for both potato types. However, there was a significant increase in the number of micro-tubers in top positions at 6 and 9 Gy treatments. Gamma irradiation effects were more noticeable in in vitro cutting tuberization in terms of number of micro-tubers produced (Figure 1 and Figure 2).

Radio-sensitivity was measured in terms of micro-tuber production following the irradiation of in vitro cuttings at $0,3,6,9,12,15$ and 20 Gy using a $1.8 \mathrm{~Gy} / \mathrm{min}$ radio-active gamma cell. The estimated lethality dose which reduces micro-tuber production by $30 \%$ and $50 \%\left(\mathrm{LD}_{30}\right.$ and $\left.\mathrm{LD}_{50}\right)$ from the irradiated cuttings was determined from the tuberization rate. The data show that diploid $S$. verrucosum Ver54 (9.4 and $12.8 \mathrm{~Gy}$ ) was more susceptible to gamma irradiation than the tetraploid $S$. tuberosum cv. Desirée (13.6 and 16 Gy) (Table 3) using which $1.8 \mathrm{~Gy} / \mathrm{min}$ dose rate gamma cell. The effects of gamma irradiation on micro-tubers size and weight were assessed as the growth reduction at $30 \%$ and $50 \%\left(\mathrm{GR}_{30}\right.$ and $\left.\mathrm{GR}_{50}\right)$ for optimal mutation induction. Similar trend of susceptibility to gamma irradiation was observed with both genotypes indicating the relative resistance of tetraploid genotype (Desirée) compared to the diploid genotype (Ver54). However, the micro-tuber size and weight were relatively radio resistance to gamma irradiation (Table 3, Figure 3 and Figure 4). However, no significant difference was observed between lethality dose of tuberization rate and growth reduction from micro-tuber size and weight for genotype. The estimated optimum dosage for mutation induction at $\mathrm{GR}_{50}$ using micro-tuber size of $13 \mathrm{~Gy}$ and $16 \mathrm{~Gy}$ and weight of 12 Gy and 15 Gy respectively for the diploid genotype (Ver54) and tetraploid genotype cv. Desirée when using a low radio-active gamma cell (1.8 Gy/min). An optimal dose for bulk production of $\mathrm{M}_{1} \mathrm{~V}_{2}$ micro-tubers was estimated to be at/around the $\mathrm{LD}_{30}$, which is $10 \mathrm{~Gy}$ for $S$. verrucosum genotype Ver54 and 12 Gy $S$. tuberosum cv. Desirée, respectively using an irradiator with an activity of $1.8 \mathrm{~Gy} / \mathrm{min}$. In addition, the effects of gamma irradiation with higher dose rate were also assessed for micro-tuber morphotypes (position, size and weight).

In our optimal culture condition described above, over $86 \%$ of nodal cuttings produced micro-tubers and one micro-tuber per cutting (Table 3). Therefore, micro-tuber population size is mainly determined by the effects gamma irradiation dose applied. The optimum dose $\left(\mathrm{LD}_{30}\right)$ of 10 and $12 \mathrm{~Gy}$ for mutation induction respectively for diploid and tetraploid potato genotype will cause reduction of $30 \%$ in number of cuttings exposed to gamma irradiation which correspond to number micro-tuber produced at that dose. Thus to produce about $1000 \mathrm{M}_{1} \mathrm{~V}_{2}$ micro-tubers using $1.8 \mathrm{~Gy} / \mathrm{min}$ gamma cell about $1400-1600 \mathrm{M}_{1} \mathrm{~V}_{1}$ cuttings will be needed.

\subsection{Bulk Mutagenesis with Optimal Mutation Induction}

Different gamma sources were used to determine optimal irradiation treatments of cuttings for both ploidy types. In total 8433 nodal cuttings were plated for the production of $4842 \mathrm{M}_{1} \mathrm{~V}_{2}$ micro-tubers for a range of treatment studies, see Table 4 for more de- 
Table 4. Effects of gamma irradiation dose in the application of the mutation induction optimal dose on tuberization of the diploid and tetraploid potato genotypes.

\begin{tabular}{|c|c|c|c|c|c|}
\hline $\begin{array}{l}\text { Genotype } \\
\text { (ploidy) }\end{array}$ & $\begin{array}{l}\text { Optimal dose } \\
\text { (Gy) }\end{array}$ & $\begin{array}{l}\text { Dose rate } \\
\text { (Gy/min) }\end{array}$ & $\begin{array}{c}\text { Number of } \\
\text { cuttings plated }\end{array}$ & $\begin{array}{c}\text { Number of } \\
\text { micro-tubers } \\
\text { produced }\end{array}$ & $\begin{array}{c}\text { Tuberization } \\
\text { rate }^{*}\end{array}$ \\
\hline \multirow{6}{*}{$\begin{array}{c}\text { Desirée } \\
(4 \times)\end{array}$} & 0 (Radiation test) & 1.8 & 40 & 39 & $97.5 \mathrm{~A}$ \\
\hline & 0 (Bulk) & 0 & 221 & 174 & $78.73 \mathrm{aA}$ \\
\hline & 12 & 1.8 & 1730 & 1048 & $60.58 \mathrm{bA}$ \\
\hline & 12 & 7.07 & 1605 & 1021 & $63.61 \mathrm{bB}$ \\
\hline & 12 & 139 & 1795 & 686 & $38.22 \mathrm{cB}$ \\
\hline & \multicolumn{2}{|l|}{ Total } & 5351 & 2929 & 54.74 \\
\hline \multirow{6}{*}{$\operatorname{Ver} 54(2 x)$} & 0 (Radiation test) & 1.8 & 37 & 32 & $86.5 \mathrm{~B}$ \\
\hline & 0 (Bulk) & 0 & 217 & 125 & $57.60 \mathrm{bB}$ \\
\hline & 10 & 1.8 & 1246 & 758 & $60.84 \mathrm{bA}$ \\
\hline & 10 & 7.07 & 1067 & 772 & $72.35 \mathrm{aA}$ \\
\hline & 10 & 139 & 552 & 258 & $46.74 \mathrm{cA}$ \\
\hline & \multicolumn{2}{|c|}{ Total } & 3082 & 1913 & 62.07 \\
\hline
\end{tabular}

${ }^{*}$ Tuberization rate (number of micro-tubers produced), data followed by the same small letter denotes no significant difference among dose rates of the genotype and the same capital letter indicates no significant difference among ploidy types at a specific dose rate.

tails. The differences observed between two genotypes are statistically significant both between and within dose rates except when using a low irradiation emitter (1.8 $\mathrm{Gy} / \mathrm{min})$ in which both genotypes exhibited similar induction rate $(\mathrm{p}>0.05)$ (Table 4$)$. While low radio-activity sources $(1.8 \mathrm{~Gy} / \mathrm{min}$ and $7.07 \mathrm{~Gy} / \mathrm{min})$ produced micro-tuber induction rates of about $60 \%$ for both ploidy types, the gamma cell with a radio-activity of $7.07 \mathrm{~Gy} / \mathrm{min}$ exhibited over $72 \%$ tuberization rate for the tetraploid cv. Desirée. Treatments using the highly radio-active source (139 Gy/min) diminished the tuberization response of both species; the effects were more lethal with respect to micro-tubers production, since only about $47 \%$ and $38 \%$ micro-tuber production rates were recorded for Ver54 and Desirée, respectively. The highly radio-active gamma cell (139 Gy/min) produced less micro-tubers than the low activity cells (1.8 and $7.07 \mathrm{~Gy} / \mathrm{min}$ ) at the same delivered dose.

The effects of the three gamma cells (with varying radio-activities) were also assessed by the quality (morphotypes) of micro-tubers produced and their location on the stolon (basal, middle and top of stolon). Likelihood ratio testing revealed a significant difference at the dose rates and between genotypes, and their interaction by nominal logistic analysis fit for position to test probability of micro-tuber occurring at basal, middle and top position on the stolon. Micro-tuber size and weight showed significant difference for proportional hazards fit analysis to reveal the probability of micro-tuber with similar size or weight as proportion (Table 5). Gamma irradiation affected micro-tuber initiation position on the cuttings, but which was mainly basal in both ploidy types. Addi- 
Table 5. Effects of likelihood ratio tests on micro-tuber position, size and weight of the two potato ploidy types using a standard delivered dose of 10 and 12 Gy but from three gamma sources of varying radio-activity emitting 1.8, 7.07 and $139 \mathrm{~Gy} / \mathrm{min}$, respectively) and control (no irradiation) treatment.

\begin{tabular}{cccccccc}
\hline \multirow{2}{*}{ Source of variation } & \multicolumn{2}{c}{ Position } & & \multicolumn{2}{c}{ size $(\mathrm{mm})$} & \multicolumn{2}{c}{ Weight (mg) } \\
\cline { 2 - 7 } & DF & ChiSquare & DF & ChiSquare & DF & ChiSquare \\
\hline Dose rate & 2 & $737.029343^{*}$ & 1 & $171.333058^{*}$ & 1 & $13444.6256^{*}$ \\
Genotype & 2 & $292030.144^{*}$ & 1 & $10159.9798^{*}$ & 1 & $7296.40488^{*}$ \\
Dose rate ${ }^{\star}$ Genotype & 2 & $7282.4983^{*}$ & 1 & $11033.0024^{*}$ & 1 & $29430.4101^{*}$ \\
\hline
\end{tabular}

$\mathrm{DF}=$ Degree of Freedom; ${ }^{*}$ denote significant differences at $5 \%$ probability level; ns = not significant.

tional micro-tubers were produced at middle and top positions of the stolon (Figure 5 and Figure 6). The diploid genotype Ver54 showed a significant increase of micro-tubers at the middle position with the highest increased rate of about $15 \%$ for $10 \mathrm{~Gy}$ using the low activity gamma source (1.8 Gy/min, Figure 5). The tetraploid cv. Desirée showed induction of micro-tubers at the top of stolon. The highest increased rate of top positioned micro-tubers was recorded for a delivered dose of $12 \mathrm{~Gy}$ using the low activity gamma source $(1.8 \mathrm{~Gy} / \mathrm{min}$ ) with a $40 \%$ tuberization rate (Figure 6 ).

Micro-tubers produced in control, untreated cuttings were characterised as mainly belonging to size classes 1 and 2 , and 1 to 3 for $S$. verrucosum and $S$. tuberosum, respectively. Gamma strength irradiation effects were observed for each of the three emitters by an increase in tuberization producing size class $2(4-6 \mathrm{~mm})$ micro-tubers for each ploidy type (Figure 5 and Figure 6). $S$. verrucosum subjected to a relatively long treatment from the low rate emitter $(1.8 \mathrm{~Gy} / \mathrm{min})$ exhibited the highest increase in tuberization rate of $15 \%$ for class 2 (Figure 5). Desirée recorded a similar increased tuberization rate of $4-6 \mathrm{~mm}$ micro-tubers of about $23 \%$ for each gamma irradiation dose rate (Figure 6). In addition, treatment of $12 \mathrm{~Gy}$ from the low emitter (1.8 Gy/min) showed an increased tuberization rate of about $10 \%$ for class $1(2-4 \mathrm{~mm})$. Desirée exhibited a decrease in tuberization rate for micro-tuber class $3(6-8 \mathrm{~mm})$, with low values recorded by both 1.8 and $139 \mathrm{~Gy} / \mathrm{min}$ gamma emitters (Figure 6).

A wide weight range of micro-tuber morphotypes (size and weight) was produced by each potato ploidy type in untreated, control conditions (Figure 5 and Figure 6). With gamma ray treatment the $S$. verrucosum genotype (Ver54, diploid) produced a high percentage of micro-tubers of about 48 and 39\%, respectively for $0-50 \mathrm{mg}$ (class 1 ) and 51 - $100 \mathrm{mg}$ (class 2) while no micro-tubers were observed for weight classes above 100 mg (classes 3 - 7) (Figure 5). The $S$. tuberosum (cv. Desirée, tetraploid) produced the highest micro-tuber production rate for class 2 micro-tubers (Figure 6). Thus the 12 Gy treatment from the highest gamma emitter $(139 \mathrm{~Gy} / \mathrm{min})$ induced the highest increase of small micro-tubers in both ploidy types. However, the effects were more pronounced for the $S$. verrucosum genotype (Ver54, diploid) with a tuberization rate about $65 \%$ for the weight class 1 . High dose treatments ( $1.8 \mathrm{~Gy} / \mathrm{min} \mathrm{Gy}$ and above) were more severe for the diploid $S$. verrucosum (Figure 5). However, all class weight ranges were 


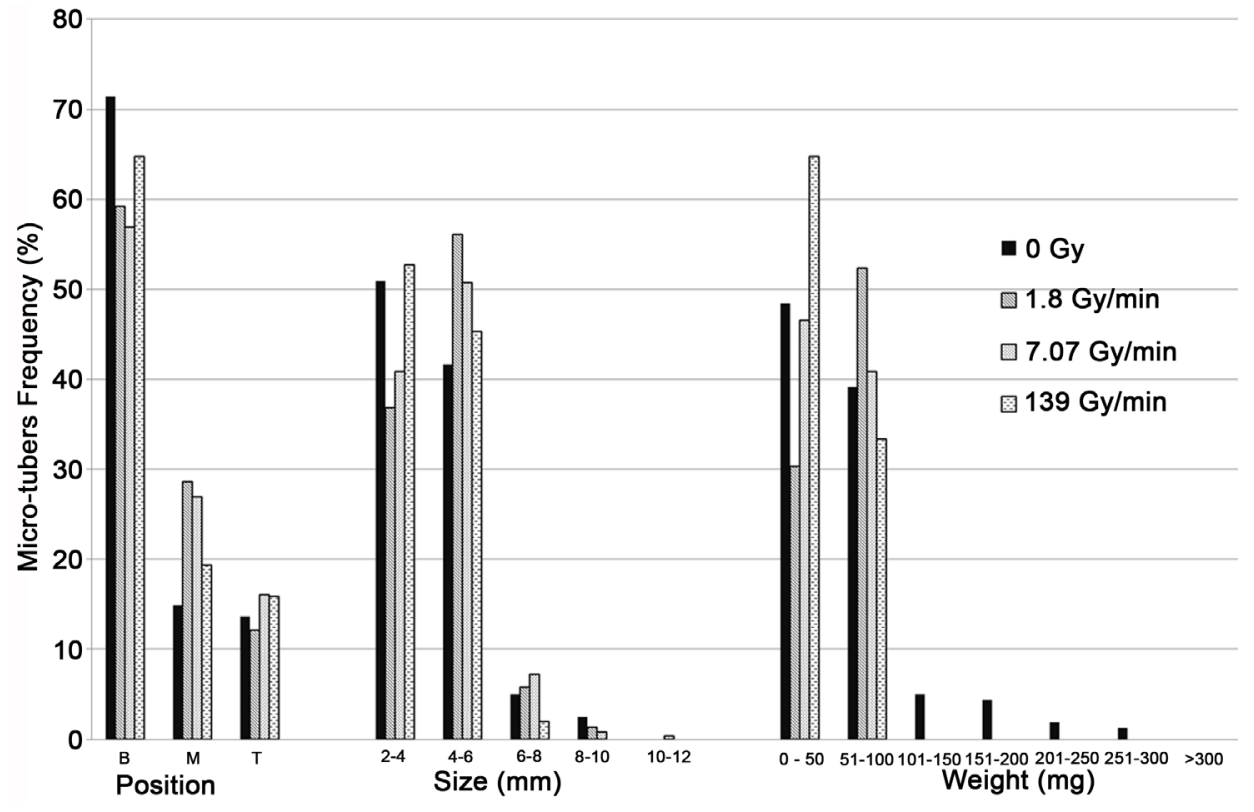

Figure 5. Effects of a gamma irradiation dose of $10 \mathrm{~Gy}$ delivered by three gamma cells of varying radio-activity $(1.80,7.07$ and $139 \mathrm{~Gy} / \mathrm{min}$ ) compared to control (no irradiation treatment) on $S$. verrucosum, Ver54 $(2 \times)$ with respect to micro-tuber position (basal, middle and top of stolon), micro-tuber size and weight frequency distribution.

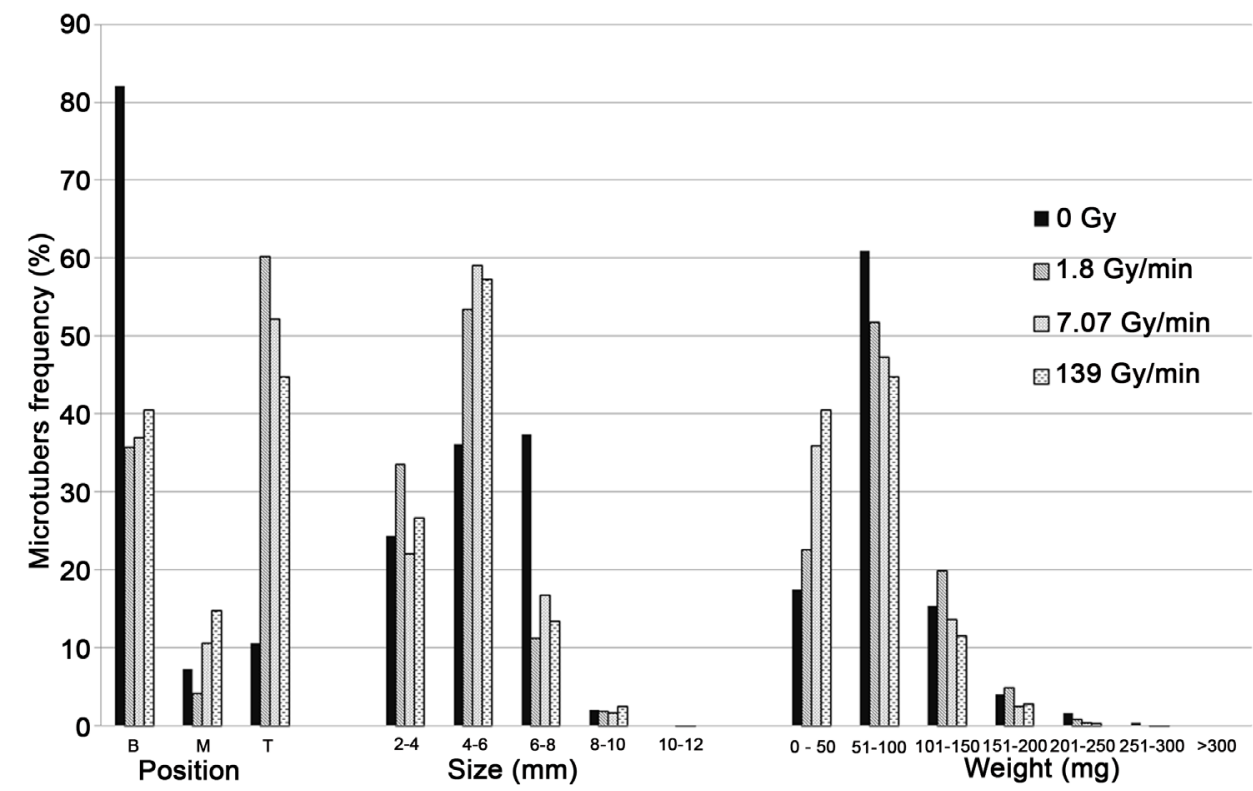

Figure 6. Effects of the gamma irradiation dose rate on the $S$. tuberosum cv. Desirée (tetraploid) with respect to micro-tube position (basal, middle and top of stolon), size and weight frequency distribution.

found for $S$. tuberosum under each gamma treatment (1.8 to $139 \mathrm{~Gy} / \mathrm{min}$ ). The low gamma emitter $(1.8 \mathrm{~Gy} / \mathrm{min})$ resulted in a slightly increased tuberization rate for weight class 3 for $S$. tuberosum (Figure 6) for 12 Gy treatment. 
In addition to the influence of ploidy and the effects of gamma irradiation on the tuberization rate and micro-tuber morphotype, some obvious visual phenotypes were observed among the mutant populations. Some colour variants were observed in the bulk micro-tuber population $\left(\mathrm{M}_{1} \mathrm{~V}_{2}\right)$ in which the diploid Ver54 was more uniformity in colour, whereas the tetraploid cv. Desirée had a high number of dark red coloured micro-tubers (Figure 7(a) and Figure 7(b)). Although Desirée is a red skinned cultivar, this trait was not expressed well in micro-tubers, and thus skin colour could not be used reliably as a trait to define mutants. Micro-tuber shape was also affected by gamma irradiation causing fusion to form twins (Figure 7(c) and Figure 7(d)). The tetraploid cv. Desirée showed more un-differentiated twin micro-tubers and included some that differentiated rapidly (Figure 8(a) and Figure 8(b)).

\section{Discussion}

The two potato ploidy types responded differently to gamma irradiation doses gamma rays from emitters varying in radio-activity. As expected the diploid genotype showed greater sensitivity than the tetraploid [26]. Higher gamma treatments ( $>15$ Gy) were more inhibitory for $S$. verrucosum than for $S$. tuberosum. The estimated lethality dose at $50 \%$ of diploid Ver54 (12.8 Gy) was lower than 16.0 Gy for $S$. tuberosum cv. Desirée (tetraploid) with a gamma irradiation rate of $1.8 \mathrm{~Gy} / \mathrm{min}(7 \mathrm{~min} 7 \mathrm{~s}$ and $8 \mathrm{~min} 53 \mathrm{~s}$ respectively) (Table 3, Figure 3 and Figure 4). Higher and more intense gamma irradiation can cause chromosomal damage in plants and therefore has significant effects on plant development including in vitro regeneration and tuberization [27] [28]. The effects of increasing gamma irradiation dose on potato tuberization are an initial delay and cessation of micro-tuber induction by cuttings. These results along with stimulation at low dose treatments were also reported previously [7]. The variation observed

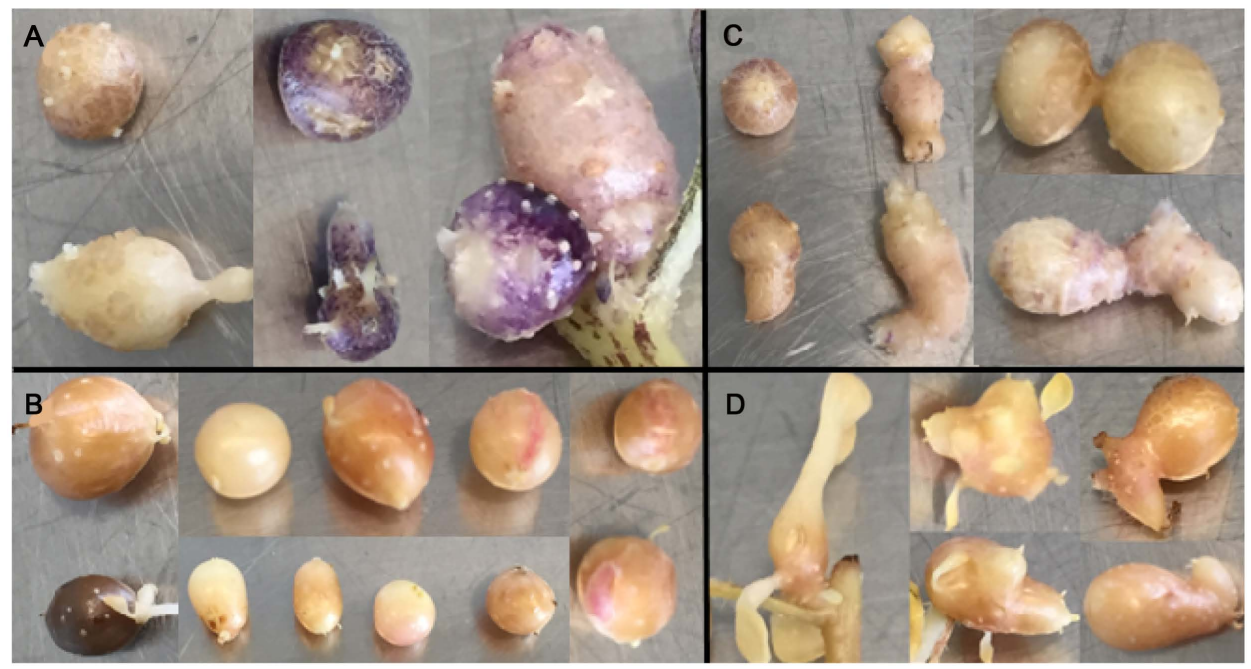

Figure 7. Colour and shape variants in micro-tubers: A. S. verrucosum genotype Ver54, (diploid) with control micro-tuber left top; B. S. tuberosum cv. Desirée (tetraploid) with control micro-tuber left top and changed shape of micro-tubers: C. S. verrucosum genotype Ver54 (diploid) and D. S. tuberosum cv. Desirée (tetraploid). 


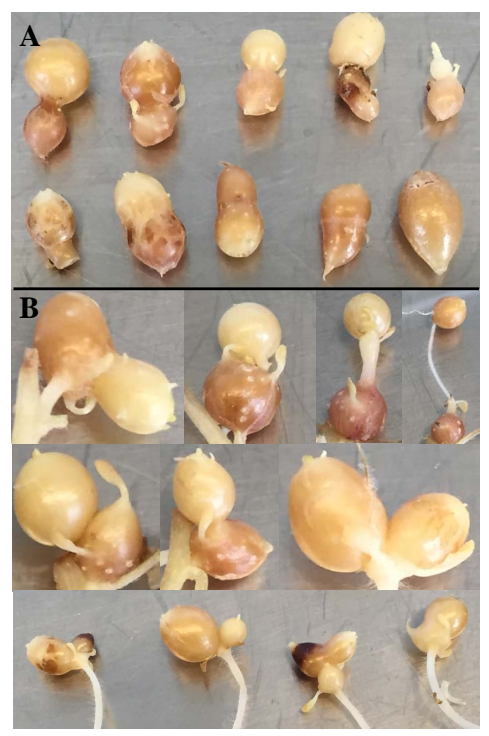

Figure 8. Deformed and differentiated morphotypes in M1V2 micro-tubers of $S$. tuberosum cv. Desirée (tetraploid): A) deformed or undifferentiated twin micro-tubers; B) Fast differentiated twin micro-tubers.

between the two ploidy types with respect to tuberization after gamma irradiation at optimal doses for mutagenesis is similar as those reported earlier [26] [29]. That relative susceptibility of the diploid potato genotype (Ver54) in comparison to the tetraploid cv. (Desirée) confirms the relative increased resistance to irradiation by higher ploidy levels: polyploidy creates a genetic buffering effect, discussed by Kodym et al. [30].

In vitro culture of vegetatively propagated crops in combination with radiation induced mutations has proven to be a valuable tool to broaden genetic variability [9] [27] [31] [32]. Ahloowalia and Maluszynski [33] indicated that ionizing radiation is a very important method to generate genetic variability that does not exist in nature nor is available to the breeder. Furthermore, previous studies showed that an advantage of physical mutagens is to induce a few mutations without disrupting the genetic background, particularly of elite breeding lines [34]. Therefore, the development of an optimal dosage for mutation induction is critical; here dose treatments of 10 and 12 Gy for tuberization rate about $70 \%$ were determined for diploid Ver54 and tetraploid cv. Desirée, respectively $1.8 \mathrm{~Gy} / \mathrm{min}$ gamma cell. The growth reduction estimated based on micro-tuber size and weight for optimum dose for mutation induction will cause reduction of tuberization, while wide range of size and weight were observed in each dose. However, Kawakami and Iwama [35] reported no significant difference on yield with respect to micro-tuber size.

The selected optimal dose for mutation induction for each genotype produced similar trends of tuberization rate per gamma dose treatment and genotype. However, the results indicate the importance of the gamma irradiation dose and irradiator activity on the micro-tuber induction. Similar findings were reported by many researchers on the effects of high gamma irradiation dose rate on other plant species/materials. A low and 
more gentle treatment is often required for sensitive target tissues (especially those with a high water content such as potato in vitro cuttings) and a low activity emitter may be preferred as treatment times (minutes rather than seconds) are easier to handle. However, in other studies chronic irradiation (low emission) was found to be yield the widest flower colour spectrum in in vitro culture of mutated chrysanthemum in comparison to acute irradiation (high dose rate) [36]. The high energy causes more damage to the irradiated tissue whereas a low dose may induce an adaptation to gamma irradiation, however, they can produce similar mutation rates [37]-[39]. Low activity gamma sources are recommended for vegetatively propagated plants because these sources allow the application of low doses to plant propagules with a high water content; more water can produce more free radicals or oxidative molecules and hence more irradiation damage [40]. Gamma cells with low dose rate (1, 8 and $7.07 \mathrm{~Gy} / \mathrm{min})$ resulted in tuberization rate around expected induction rate $(70 \%)$ are recommended for potato mutation breeding through in vitro cutting tuberization.

Regardless of ploidy, both potato types were affected by gamma irradiation treatments. Different effects were observed in micro-tuber production with respect to position, size and weight (Figure 5 and Figure 6). Thus the results of micro-tuber position from basal to middle or top showed that the potato cuttings may have dissipated the effects of gamma irradiation on tuberization by shoot initiation with later induction of micro-tubers either at middle or top position. Gamma irradiation induces more small sized micro-tubers (less than $6 \mathrm{~mm}$ ) compared to untreated cuttings. Similar results were reported by Nistor et al. [41]. The weight of micro-tuber shows a polyploidy influence and also the relative resistance to gamma irradiation of $S$. tuberosum cv. Desirée (tetraploid) with regard to micro-tuber weight in comparison to the $S$. verrucosum genotype (Ver54, diploid). Gamma irradiation induced a micro-tuber weight class below $100 \mathrm{mg}$ in the diploid genotype and this was maintained in all weight categories with a similar frequency as the untreated cuttings. These results demonstrate the interaction between ploidy and radio-sensitivity. Nevertheless, micro-tuber size has been reported to have no significant associations with growing period, number of tubers, and tuber fresh and dry yield [35]. That allows the recovery of all mutations from the different class size of micro-tuber produced by gamma irradiation independently of the ploidy level.

Mutant micro-tuber populations are convenient for end users. In this work the populations studied were $\mathrm{M}_{1} \mathrm{~V}_{2}$ and hence some chimera dissolution has occurred. Although chimera dissolution was not measured, a recent report in banana suggests that these can be dissolved after one or two rounds of subculture [32]. The micro-tuber mutant populations produced may be subject to screens in detecting desired mutants for traits and genes. The micro-tuber mutant populations are being screened for potato Cyst nematodes and Blight resistance.

\section{Conclusion}

In vitro cuttings provide a convenient target for mutation induction and subsequent micro-tuber production provides convenient mutant populations for subsequent muta- 
tion detection/screening. Optimal dose rates for gamma irradiation of in vitro cuttings have been determined for two potato ploidy types, one diploid, one tetraploid, with respect to the development of mutant $\left(\mathrm{M}_{1} \mathrm{~V}_{2}\right)$ micro-tuber populations. Thus, ploidy level and gamma irradiation dose rate were found to affect both the potato micro-tuberization as well as the morphotypes of the micro-tubers produced.

\section{Conflict of Interest}

The authors have no conflict of interest related to the work described in this manuscript.

\section{Acknowledgements}

This work was funded by Food and Agriculture Organization of the United Nations and the International Atomic Energy Agency through their Joint FAO/IAEA Programme of Nuclear Techniques in Food and Agriculture. We acknowledge the valuable support of A. Draganitsch and B. Guenter of the PBGL.

\section{References}

[1] (1992) FAOSTAT Agriculture: FAO Statistical Database. http://faostat3.fao.org/download/Q/QC/E. Accessed 06 Dec 2014

[2] Mahfouze, S.A., Esmael, A.M. and Mohasseb, H.A.A. (2012) Genetic Improvement of Potato Microtuber Production in Vitro by Gamma Irradiation. Biotecnología Aplicada, 29, 253-257.

[3] Dalton, E., Griffin, D., Gallagher, T.F., de Vetten, N. and Milbourne, D. (2013) The Effect of Pyramiding Two Potato Cyst Nematode Resistance Loci to Globodera pallida Pa2/3 in Potato. Molecular Breeding, 31, 921-930. http://dx.doi.org/10.1007/s11032-013-9845-9

[4] Cingel, A., Savić, J., Ćosić, T., Zdravković-Korać, S., Momčilović, I., Smigocki, A. and Ninković, S. (2014) Pyramiding Rice Cystatin OCI and OCII Genes in Transgenic Potato (Solanum tuberosum L.) for Resistance to Colorado Potato Beetle (Leptinotarsadecemlineata Say). Euphytica, 198, 425-438. http://dx.doi.org/10.1007/s10681-014-1119-z

[5] Sharma, R., Bhardwaj, V., Dalamu, D., et al. (2014) Identification of Elite Potato Genotypes Possessing Multiple Disease Resistance Genes through Molecular Approaches. Scienta Horticulturae, 179, 204-211. http://dx.doi.org/10.1016/j.scienta.2014.09.018

[6] Davies, L.J. and Elling, A.A. (2015) Resistance Genes against Plant-Parasitic Nematodes: A Durable Control Strategy? Nematology, 17, 249-263. http://dx.doi.org/10.1163/15685411-00002877

[7] Al-Safadi, B., Ayyoubi, Z. and Jawdat, D. (2000) The Effect of Gamma Irradiation on Potato Microtuber Production in Vitro. Plant Cell Tissue and Organ Culture, 61, 183-187. http://dx.doi.org/10.1023/A:1006477224536

[8] Grüneberg, W., Mwanga, R., Andrade, M. and Espinoza, J. (2009) Selection Methods Part 5: Breeding Clonally Propagated Crops. In: Ceccarelli, S., Guimarães, E.P. and Weltzien, E., Eds., Plant Breeding and Farmer Participation, FAO, Rome, 275-322.

[9] Cheng, L., Yang, H., Lin, B., Wang, Y., Li, W., Wang, D. and Zhang, F. (2010) Effect of Gamma-Ray Radiation on Physiological, Morphological Characters and Chromosome Aberrations of Mini-Tubers in Solanum tuberosum L. International Journal of Radiation Biology, 86, 791-799. http://dx.doi.org/10.3109/09553002.2010.484478 
[10] Gopal, J. and Oyama, K. (2005) Genetic Base of Indian Potato Selections as Revealed by Pedigree Analysis. Euphytica, 142, 23-31. http://dx.doi.org/10.1007/s10681-005-0448-3

[11] Piao, X.C., Chakrabarty, D., Hahn, E.J. and Paek, K.Y. (2003) A Simple Method for Mass Production of Potato Microtubers Using a Bioreactor System. Current Science, 84, 11291132.

[12] Badoni, A. and Chauhan, J.S. (2010) Importance of Potato Micro Tuber Seed Material for Farmers of Uttarakhand Hills. International Journal of Sustainable Agriculture, 2, 1-9.

[13] Pruski, K., Astatkie, T., Duplessis, P., Stewart, L., Nowak, J. and Struik, P.C. (2003) Manipulation of Microtubers for Direct Field Utilization in Seed Production. American Journal of Potato Research, 80, 173-181. http://dx.doi.org/10.1007/BF02855689

[14] Asseyeva, T. (1931) Bud Mutations in the Potato. Bulletin of Applied Botany (Leningrad), 27, 135-217.

[15] Cieśla, K. and Eliasson, A.C. (2002) Influence of Gamma Radiation on Potato Starch Gelatinization Suited by Differential Scanning Calorimetry. Radiation Physics Chemistry, 64, 137-148. http://dx.doi.org/10.1016/S0969-806X(01)00458-3

[16] Muth, J., Hartje, S., Twyman, R.M., Hofferbert, H.R., Tacke, E. and Prufer, D. (2008) Precision Breeding for Novel Starch Variants in Potato. Plant Biotechnology Journal, 6, 576-558. http://dx.doi.org/10.1111/j.1467-7652.2008.00340.x

[17] Li, H.Z., Zhou, W.J., Zhang, Z.J., Gu, H.H., Takeuchi, Y. and Yoneyama, K. (2005) Effect of $\gamma$-Radiation on Development, Yield and Quality of Microtubers in Vitro in Solanum tuberosum L. Biologia Plantarum, 49, 625-628. http://dx.doi.org/10.1007/s10535-005-0062-1

[18] Nayak, C.A., Suguna, K., Narasimhamurthy, K. and Rastogi, N.K. (2007) Effect of Gamma Irradiation on Histological and Textural Proprieties of Carrot, Potato and Beetroot. Journal of Food Engineering, 79, 765-770. http://dx.doi.org/10.1016/j.jfoodeng.2006.02.040

[19] Baskaran, R., Devi, A.U., Nayak, C.A., Kudachikar, V.B. and Prakash, M.N.K. (2007) Effect of Low-Dose $\gamma$-Irradiation on the Shelf Life and Quality Characteristics of Minimally Processed Potato Cubes under Modified Atmosphere Packaging. Radiation Physics and Chemistry, 76, 1042-1049. http://dx.doi.org/10.1016/j.radphyschem.2006.10.004

[20] Al-Safadi, B. and Arabi, M.I.E. (2003) In Vitro Induction, Isolation and Selection of Potato Mutants Resistant to Late Blight. Journal of Genetics \& Breeding, 57, 359-364.

[21] Al-Safadi, B. and Arabi, M.I.E. (2007) In Vitro induction, Isolation and Selection of Potato Mutants Tolerant to Salinity. Advances in Horticultures Sciences, 20, 127-132.

[22] Albiski, F., Najla, S., Sanoubar, R., Alkabani, N. and Murshed, R. (2012) In Vitro Screening of Potato Lines for Drought Tolerance. Physiology and Molecular Biology of Plants, 18, 315-321. http://dx.doi.org/10.1007/s12298-012-0127-5

[23] Matijevic, M., Bado, S., Lagoda, P.J.L. and Forster, B.P. (2013) Impact of Induced Mutations in Plant Breeding. International Conference on Plant Genetics and Breeding Technologies, Vienna, 18-20 February 2013, 45-48.

[24] Murashige, T. and Skoog, F. (1962) A Revised Medium for Rapid Growth and Bioassays with Tobacco Tissue Cultures. Phyiologia Plantarum, 15, 473-497. http://dx.doi.org/10.1111/j.1399-3054.1962.tb08052.x

[25] Mba, C., Afza, R., Bado, S. and Jain, S.M. (2010) Induced Mutagenesis in Plants Using Physical and Chemical Agents. In: Davey, M.R. and Anthony, P., Eds., Plant Cell Culture: Essential Methods, Wiley \& Sons Ltd., Chichester, 111-130. http://dx.doi.org/10.1002/9780470686522.ch7

[26] Novak, F.J., Afza, R., van Duren, M. and Omar, M.S. (1990) Mutation Induction by Gamma 
Irradiation of in Vitro Cultured Shoot-Tips of Banana and Plantain (Musa cvs). Tropical Agriculture, 67, 21-26.

[27] Alikamanoğlu, S. (2002) Efficiency of the Gamma Radiation in the Induction of in Vitro Somatic Mutations. Journal of Cell and Molecular Biology, 1, 19-24.

[28] Yaycili, O. and Alikamanoğlu, S. (2012) Induction of Salt-Tolerant Potato (Solanum tuberosum L.) Mutants with Gamma Irradiation and Characterization of Genetic Variations via RAPD-PCR Analysis. Turkish Journal of Biology, 36, 405-412.

[29] Jain, S.M., Till, B., Suprasanna, P. and Roux, N. (2011) Mutations and Cultivar Development of Banana. In: Pillay, M. and Tenkouano, A. Eds., Banana Breeding: Progress and Challenges, CRC Press, New York, 203-217. http://dx.doi.org/10.1201/b10514-11

[30] Kodym, A., Afza, R., Forster, B.P., Ukai, Y. and Nakagawa, H. (2012) Methodology for Physical and Chemical Mutagenic Treatments. In: Shu, Q.Y., Forster, B.F. and Nakagawa, H., Eds., Plant Mutation Breeding and Biotechnology, CABI, FAO, Oxfordshire, Rome. 169-180. http://dx.doi.org/10.1079/9781780640853.0169

[31] Elias, R., Till, B.J., Mba, C. and Al-Safadi, B. (2009) Optimizing Tilling and Eco-Tilling Techniques for Potato (Solanum tuberosum L.). BMC Research Notes, 2, 141-145. http://dx.doi.org/10.1186/1756-0500-2-141

[32] Jankowicz-Cieslak, J., Huynh, O.A., Brozynska, M., Nakitandwe, J. and Till, B.J. (2012) Induction, Rapid Fixation and Retention of Mutations in Vegetatively Propagated Banana. Plant Biotechnology Journal, 10, 1056-1066. http://dx.doi.org/10.1111/j.1467-7652.2012.00733.x

[33] Ahloowalia, B. and Maluszynski, M. (2001) Induced Mutations-A New Paradigm in Plant Breeding. Euphytica, 118, 167-173. http://dx.doi.org/10.1023/A:1004162323428

[34] Bado, S., Forster, B.P., Nielen, S., Ghanim, A., Lagoda, P.J.L., Till, B.J. and Laimer, M. (2015) Plant Mutation Breeding: Current Progress and Future Assessment. Plant Breeding Reviews, 39, 23-88. http://dx.doi.org/10.1002/9781119107743.ch02

[35] Kawakami, J. and Iwama, K. (2012) Effect of Potato Microtuber Size on the Growth and Yield Performance of Field Grown Plants. Plant Production Science, 15, 144-148. http://dx.doi.org/10.1626/pps.15.144

[36] Nagatomi, S. and Degi, K. (2009) Mutation Breeding of Chrysanthemum by Gamma Field Irradiation and in Vitro Culture. In: Shu, Q.Y., Ed., Induced Plant Mutations in the Genomics Era, FAO, Rome, 258-261.

[37] Sparrow, A.H. and Singleton, W.R. (1953) The Use of Radio-Cobaltasa Source of Gammarays and Some Effects of Chronicir Radiation on Growing Plants. American Naturalist, 87, 29-48. http://dx.doi.org/10.1086/281753

[38] Nybom, N., Gustafsson, A., Granhall, I. and Ehrenberg, L. (1956) The Genetic Effects of Chronic Gamma Irradiation in Barley. Hereditas, 42, 74-84.

http://dx.doi.org/10.1111/j.1601-5223.1956.tb03012.x

[39] Sparrow, A.H. (1961) Types of Ionizing Radiation and Their Cytogenetic Effects. Proceedings of Symposium on Mutation and Plant Breeding, Cornell University, 28 November-2 December 1960, 55-119.

[40] Esnault, M.A., Legue, F. and Chenal, C. (2010) Ionizing Radiation: Advances in Plant Response. Environmental and Experimental Botany, 68, 231-237. http://dx.doi.org/10.1016/j.envexpbot.2010.01.007

[41] Nistor, A., Campeanu, G., Atanasiu, N., Chiru, N. and Karácsonyi, D. (2010) Influence of Genotype on Microtuber Production. Notulae Botanicae Horti Agrobotanici Cluj-Napoca, 38, 209-221. 
Submit or recommend next manuscript to SCIRP and we will provide best service for you:

Accepting pre-submission inquiries through Email, Facebook, LinkedIn, Twitter, etc. A wide selection of journals (inclusive of 9 subjects, more than 200 journals)

Providing 24-hour high-quality service

User-friendly online submission system

Fair and swift peer-review system

Efficient typesetting and proofreading procedure

Display of the result of downloads and visits, as well as the number of cited articles

Maximum dissemination of your research work

Submit your manuscript at: http://papersubmission.scirp.org/

Or contact ajps@scirp.org 